\title{
Modeling of Skylight on Dome Shaped Roof of Low Energy Adobe House Located in New Delhi (India)
}

\author{
Arvind Chel ${ }^{1, *}$ and G.N.Tiwari ${ }^{2}$ \\ ${ }^{1,2}$ Centre for Energy Studies, Indian Institute of Technology Delhi, New Delhi, India \\ * Corresponding author. Tel: +919968144689 Fax: +91 26581121, E-mail:dr.arvindchel@gmail.com
}

\begin{abstract}
The daylight factor model given by Charted Institute of Building Services Engineers (CIBSE) was modified in this paper to incorporate time variations with respect to zenith angle $(\theta z)$ and vertical height $(h)$ of working surface above ground surface which was normalized with central height $(\mathrm{H})$ of skylight dome. The modified model contains constant exponents which are determined using linear regression analysis based on hourly experimental data of inside and outside illuminance for each month of the year 2007-2008. The prediction of modified model is found in good agreement with experimental observed inside illuminance data on the basis of values of root mean square percentage error (e) and correlation coefficient (r). The annual average daylight factor values for big and small dome skylight rooms are determined as $2.3 \%$ and $4.4 \%$ respectively. The energy saving potential of skylight rooms for selected climatic locations in India is also presented in this paper. This paper also investigates embodied energy of an existing eco-friendly and low embodied energy adobe house with dome shape roof located at Solar Energy Park inside IIT Delhi campus in New Delhi (India). Based on embodied energy analysis, the energy payback time for the adobe house was determined as 18 years. The embodied energy per unit floor area of reinforced cement concrete (R.C.C.) building $\left(3702.3 \mathrm{MJ} / \mathrm{m}^{2}\right)$ is quiet higher as compared to adobe house embodied energy $\left(2298.8 \mathrm{MJ} / \mathrm{m}^{2}\right)$.
\end{abstract}

Keywords: Skylight, Dome shape roof, Daylight Factor, Illumination, Mud house

\section{Nomenclature}

$A_{e} \quad$ effective area........................... $m^{2}$

$A_{f} \quad$ floor area ............................. $m^{2}$

$A_{s} \quad$ working surface area ................. . $m^{2}$

$B_{F} \quad$ ballast factor or efficiency... $\quad 0 \leq B F \leq 1$

DF percentage daylight factor $\quad \%$

$I_{d}$ diffuse solar radiation

$L_{i} \quad$ illuminance inside the room lux or $\mathrm{lm} / \mathrm{m}^{2}$

$M_{F}$ maintenance factor $\quad 0 \leq M F \leq 1$

$n$ constant exponent $\quad \ldots \ldots . \quad O_{F}$

$R \quad$ average reflectance of surface $0 \leq R \leq 1 \quad U_{F}$
$H \quad$ height of source

$A_{g} \quad$ total area of glazing

At total area of room-surface

correction factor for glazing

vertical height above ground surface $-m \leq .9$

global solar radiation

outside diffuse illuminance

constant exponent

glazing orientation factor

utilization factor $m$

$m^{2}$

$m^{2}$

$0.5 \leq C \leq 0.9$

$W / m^{2}$

lux or $\mathrm{lm} / \mathrm{m}^{2}$

$0.97 \leq \stackrel{O F}{O F} \leq 1.55$

$0 \leq U F \leq 1$

\section{Greek letters}
$\varepsilon$ light source luminous efficacy
$\operatorname{lm} / W$
$\varnothing$ total luminous flux
lumen
$\tau$ transmittance of glazing
$0 \leq \tau \leq 1$
$\theta$ vertical angle of visible sky from horizon degrees
$\theta_{Z}$ zenith angle
degrees

\section{Introduction}

Daylighting is an important issue in modern architecture affecting the functional arrangement of spaces, occupant comfort (visual and thermal), structure and energy use in building [1]. Daylight is considered as the best source of light for good color rendering and its quality is the one light source that most closely matches with human visual response. It gives a sense of cheeriness and brightness that can have a significant positive impact on the people. The amount of daylight penetrating a building is mainly through window openings which provide the dual function not only of admitting light for indoor environment with a more attractive 
and pleasing atmosphere, but also allowing people to maintain visual contact with the outside world. People desire good natural lighting in their living environments $[2,3]$.

The energy consumption of lighting in buildings is a major contributor to carbon emissions, often estimated as $20-40 \%$ of the total building energy consumption as reported by Building Research Establishment (BRE) energy consumption guide [4] and Chartered Institute of Building Services Engineers (CIBSE) [5]. Furthermore, the heat gains produced from artificial and natural lighting have an important influence upon he ating and cooling loads reported by Peacock et al. [6]. Using controls for demonstrating the optimized configuration for daylight supplemented electrical lights is well-documented by Greenup et al. [7], Reinhart [8] and Li and Lam [9], with particular interest on the effect of thermal loads reported by Franzetti et al. [10]. However, the more advanced and material-based solutions were reported by Lee et al. [11], Tong et al. [12] and Smith [13] for optimizing daylight. They provide innovative solutions for reducing lighting-energy consumptions.

With the project considering a large number of buildings, it is important that the approach should be as efficient as possible with regards to the available time as reported by Reinhart and Fitz [14]. While building-simulation packages and time-series techniques can be used for detailed predictions of lighting use [15]; they can be both time consuming and unnecessary for obtaining first-order estimate. The annual variation in daylight availability in UK can be represented using data reported by CIBSE [16] and Hunt [17,18]. The domestic lighting demand was determined using simple model developed by Stokes et al. [19]. The economics of lighting retrofits for emission reduction was reported by Mahlia et al. [20]. Daylighting is one of the basic components of passive solar building design and its estimation is essential. Laouadi et al. [21] had reported that the daylight factor of building depends upon position of light source with respect to the room orientation, the room geometry, the optical characteristics of the room indoor surfaces, any outdoor obstructions and the optical behaviour (transmission, reflection and light scattering) of the fenestration system through which light is admitted into the room space. Daylight coefficient is independent of sky luminance distribution as reported by Tregenza and Waters [22]. Recently, calculating indoor natural illuminance in overcast sky conditions was reported by Rosa et al. [23]. In India and many parts of the world, the availability of measured outside illuminance values are very few. The Indian climate is generally clear with overcast conditions prevailing through the months of June-September, which provides good potential to daylighting in buildings as reported by Joshi et al. [24]. This paper investigates a mathematical model for existing skylight integrated dome shaped mud-house to estimate daylight factor based on the modifications in the model developed by CIBSE [25]. The daylight factor model developed by CIBSE [25] was validated for ground surface illuminance by Chel et al. [2] using experimental data of the existing building. The model developed by CIBSE [25] does not include time variation in a day and vertical height $(\mathrm{h})$ of the work plane above ground surface. Hence, there is need for the modification in the model developed by CIBSE [25] to incorporate vertical height (h) normalized with respect to central height $(\mathrm{H})$ of the skylight room and time variations in terms of zenith angle (hz). This concept of modeling for skylight is rarely reported in the literature for New Delhi composite climate. The constant exponents in the modified model were determined on the basis of linear regression analysis which is explained in depth in this paper. The values of exponent were determined based on hourly inside and outside illuminance data for typical clear day in each month.

Using the modified model, the daylight factor is determined for three different work planes at different vertical heights (h) from ground surface, i.e. at $\mathrm{h}=0$ (or ground surface), $0.75 \mathrm{~m}$ and 
$1.5 \mathrm{~m}$ above ground surface. The study of work plane at ground level implicates to the students seating on floor and reading and writing in rural village schools in India. The vertical height of $0.75 \mathrm{~m}$ imp licates to reading on w ork plane (or table) in modern schools and colleges in India while the $1.5 \mathrm{~m}$ vertical height implicates to standing posture of a working person like engineer in the factory (or teacher in school/conference room). The daylight factor values using modified model and experimental data were tabulated and presented in this paper. The energy saving potential of the skylight big and small domes for different selected climatic conditions is reported in this paper.

The annual average artificial lighting energy saving potential and corresponding $\mathrm{CO} 2$ emission mitigation were evaluated for the existing building by Chel et al. [2]. The research pertaining to energy savings due to existing experimental setup of mud-house integrated with an earth to air heat exchanger and embodied energy analysis of building were respectively reported by Chel and Tiwari [26,27]. The existing dome shape building is found to be a promising example of sustainable and low carbon building (or green building) integrated with stand-alone photovoltaic reported by Chel and Tiwari [28].

\section{Pyramid shape skylight over dome shape roof of Mudhouse}

Laouadi and Atif [29] and Chel et al. [2] had reported other different skylight shapes for daylighting in buildings. The existing mud-house has vault (or dome shape) roof structure integrated with pyramid shape skylight as shown by the pictorial view in Fig.1. The inside view of skylight circular aperture is also shown in Fig.1.

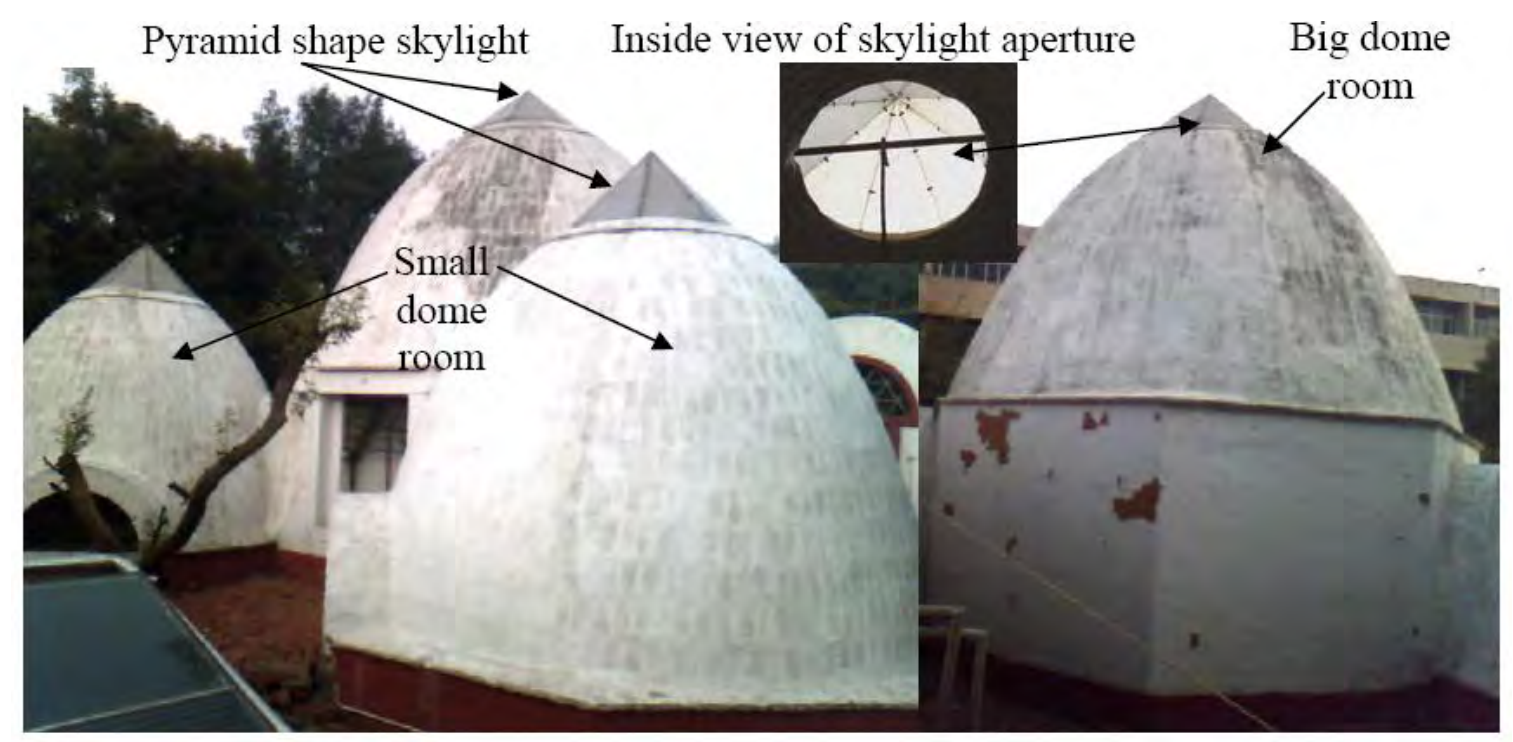

Fig. 1 Pyramid shape skylight over the dome shaped roof of Mudhouse

\section{Percentage daylight factor, DF (\%) for the naturally illuminated work plane}

The percentage daylight factor, DF (\%) is the percentage ratio of inside illuminance, Li (lux) on the horizontal work plane and outside diffuse illuminance, Lo (lux) on horizontal surface. The daylight factor for skylight integrated dome shape building at ground level is given by Eq.(1) developed by Chartered Institute of Building Services Engineers (CIBSE) [25] and validated by Chel et al. [2] as follows: 


$$
D F=\left[\frac{L_{i}}{L_{o}}\right] \times 100=\left[\frac{\tau \times C \times A_{g} \times \theta \times O_{F}}{A_{t} \times\left(1-R^{2}\right)}\right]
$$

The various parameters in Eq. (1) are tabulated with their values considered in Table 1. The variation of daylight factor (\%) with the time of the day and vertical height $(\mathrm{h})$ above ground surface is developed by Chel et al.[30] and expressed in the Eq. (2) as follows:

$D F=\left[\frac{L_{i}}{L_{o}}\right] \times 100=\left[\frac{\tau \times C \times A_{g} \times \theta \times O_{F}}{A_{t} \times\left(1-R^{2}\right)}\right] \times\left(1+\frac{h}{H}\right)^{m}\left(\cos \theta_{z}\right)^{n}$

Line equation can be easily written as follows:

$Y^{\prime}=M^{\prime}\left[X^{\prime}\right]+C^{\prime}$

This Eq.(3) of line is represented for following Eq.(3) as follows:

$$
\begin{aligned}
& \ln \left[\frac{L_{i}}{L_{o}} \times 100\right]=\left[n \times \ln \left(\cos \theta_{z}\right)\right]+\left\{m \times \ln \left(1+\frac{h}{H}\right)+\ln \left[\frac{\tau \times C \times A_{g} \times \theta \times O_{F}}{A_{t} \times\left(1-R^{2}\right)}\right]\right\} \\
& Y^{\prime}=\ln \left[\frac{L_{i}}{L_{o}} \times 100\right] \text { and } X^{\prime}=\left[\ln \left(\cos \theta_{z}\right)\right] \\
& m=\frac{\left\{C^{\prime}-\ln \left[\frac{\tau \times C \times A_{g} \times \theta \times O_{F}}{A_{t} \times\left(1-R^{2}\right)}\right]\right\}}{\ln \left(1+\frac{h}{H}\right)}
\end{aligned}
$$

Where, $n=M^{\prime}=$ slope of line and $C^{\prime}=$ intercept of line on $Y^{\prime}$ axis

The total power of lighting, $\mathrm{P}(\mathrm{W})$ can be determined by considering the artificial light source luminous efficacy, $\varepsilon(\mathrm{lm} / \mathrm{W})$ and efficiency of ballast, $\mathrm{B}_{\mathrm{F}}$ (or ballast factor). The total power of artificial electrical lighting required for the measured amount of total luminous flux, $\varnothing$ (lumen) from the existing skylight in building can be determined mathematically by Eq.(7) using Jenkins and Newborough [31] as follows:

$P=\left[\frac{\varnothing}{B_{F} \times \varepsilon}\right]$

$\varnothing=\left[\mathrm{L}_{\mathrm{i}} \times A_{s}\right]$

Where, $\mathrm{L}_{\mathrm{i}}$ is measured illuminance level (lux or lumen $/ \mathrm{m}^{2}$ ) inside the skylight building on the horizontal working surface area, As $\left(\mathrm{m}^{2}\right)$.

The total lighting-energy consumption, $\mathrm{E}(\mathrm{W}$ h/day) can be determined by multiplying total power of lighting, $\mathrm{P}(\mathrm{W})$ and required number of hours of operation per day, $\mathrm{N}(\mathrm{h} /$ day). The total lighting-energy consumption can be expressed mathematically using Eq.(9) as follows:

$\mathrm{E}=[P \times N]$ 
Table 1. Values of parameters considered for daylight factor estimation

\begin{tabular}{|c|c|c|c|c|}
\hline No. & Parameter & Value & Parameter & Value \\
\hline 1 & $\begin{array}{l}\text { Total area of room surfaces in } \\
\text { big dome }\left(A_{t}, m^{2}\right)\end{array}$ & 80 & $\begin{array}{l}\text { Total area of room surfaces in } \\
\text { small dome }\left(\mathrm{A}_{t}, \mathrm{~m}^{2}\right)\end{array}$ & 25 \\
\hline 2 & Floor area of big dome $\left(\mathrm{A}_{\mathrm{f}}, \mathrm{m}^{2}\right)$ & 26 & $\begin{array}{l}\text { Floor area of small dome }\left(\mathrm{A}_{\mathrm{f}},\right. \\
\left.\mathrm{m}^{2}\right)\end{array}$ & 5 \\
\hline 3 & Transmittance of glazing $(\tau)$ & 0.8 & $\begin{array}{l}\text { Vertical angle of visible sky from } \\
\text { horizon ( } \theta \text {, degrees) }\end{array}$ & 90 \\
\hline 4 & $\begin{array}{l}\text { Correction factor for glazing } \\
\text { due to poor maintenance/dust } \\
(0.5 \leq \mathrm{C} \leq 0.9)\end{array}$ & 0.6 & $\begin{array}{l}\text { Vertical height of work plane } \\
\text { above floor surface (h, m) } \\
{[0,0.75 \mathrm{~m}, 1.5 \mathrm{~m}]}\end{array}$ & $0,0.75,1.5$ \\
\hline 5 & $\begin{array}{l}\text { Orientation factor for glazing } \\
\left(0.97 \leq \mathrm{O}_{\mathrm{F}} \leq 1.55\right)\end{array}$ & 1 & $\begin{array}{l}\text { Average reflectance of all room- } \\
\text { surfaces }(0 \leq R \leq 1)\end{array}$ & 0.3 \\
\hline 6 & $\begin{array}{l}\text { Total area of glazing }\left(\mathrm{A}_{\mathrm{g}}, \mathrm{m}^{2}\right) \\
\text { for big dome }\end{array}$ & 2.6 & $\begin{array}{l}\text { Total area of glazing }\left(\mathrm{A}_{\mathrm{g}}, \mathrm{m}^{2}\right) \text { for } \\
\text { small dome }\end{array}$ & 1.5 \\
\hline 7 & Ballast factor $\left(\mathrm{B}_{\mathrm{F}}\right)$ & 0.9 & $\begin{array}{l}\text { Artificial light luminous efficacy } \\
(\varepsilon, 1 \mathrm{~m} / \mathrm{W}) \text { (CFL lamp) }\end{array}$ & 40 \\
\hline
\end{tabular}

\section{Results and discussion:}

Based on experimental data of inside and outside diffuse illuminance, the daily average experimental value of percentage daylight factor is determined and compared with daily average predicted value of daylight factor using modified model Eq.(2) for each month in Table 2 (DF- Daylight Factor (\%), B- Big Dome, S-Small Dome with h= 0 cm, 75 cm, $150 \mathrm{~cm}$ ).

Table 2. Experimental comparison of daylight factor with developed skylight model

\begin{tabular}{llcccccc}
\hline Month & $\begin{array}{l}\text { Model/ } \\
\text { Experimental } \\
\text { values }\end{array}$ & $\begin{array}{c}\text { DF-0 B } \\
\mathbf{( \% )}\end{array}$ & $\begin{array}{c}\text { DF-75 B } \\
\mathbf{( \% )}\end{array}$ & $\begin{array}{c}\text { DF-150 B } \\
\mathbf{( \% )}\end{array}$ & $\begin{array}{c}\text { DF-0 S } \\
\mathbf{( \% )}\end{array}$ & $\begin{array}{c}\text { DF-75 S } \\
\mathbf{( \% )}\end{array}$ & $\begin{array}{c}\text { DF-150 S } \\
\text { (\%) }\end{array}$ \\
\hline Jan & Model & 1.54 & 1.99 & 2.41 & 2.85 & 3.23 & 3.97 \\
& Experimental & 1.58 & 1.90 & 2.35 & 2.80 & 3.37 & 4.15 \\
\hline Feb & Model & 1.54 & 1.58 & 2.20 & 2.86 & 2.87 & 3.34 \\
& Experimental & 1.19 & 1.57 & 2.08 & 2.48 & 3.00 & 3.52 \\
\hline Mar & Model & 1.51 & 2.05 & 2.89 & 2.86 & 5.39 & 6.30 \\
& Experimental & 1.52 & 2.11 & 2.99 & 4.02 & 5.49 & 7.07 \\
\hline Apr & Model & 1.54 & 2.55 & 3.22 & 2.88 & 4.54 & 5.57 \\
& Experimental & 1.91 & 2.55 & 3.20 & 3.55 & 4.56 & 6.20 \\
\hline May & Model & 1.54 & 2.59 & 2.97 & 2.81 & 4.51 & 6.30 \\
& Experimental & 1.78 & 2.41 & 2.91 & 3.78 & 4.80 & 6.07 \\
\hline \multirow{2}{*}{ Jun } & Model & 1.53 & 2.02 & 2.42 & 2.84 & 4.24 & 6.25 \\
& Experimental & 1.61 & 2.07 & 2.53 & 3.00 & 4.49 & 6.61 \\
\hline Aul & Model & 1.51 & 2.09 & 2.75 & 2.85 & 4.50 & 5.60 \\
& Experimental & 1.95 & 2.40 & 2.86 & 3.74 & 5.14 & 6.10 \\
\hline Sept & Model & 1.53 & 2.26 & 2.82 & 2.83 & 4.11 & 5.39 \\
& Experimental & 2.02 & 2.45 & 2.92 & 3.55 & 4.41 & 5.46 \\
\hline Oct & Experimental & 1.50 & 2.22 & 2.94 & 2.81 & 3.95 & 5.16 \\
& Model & 1.52 & 2.47 & 2.95 & 2.69 & 3.87 & 5.31 \\
\hline Nov & Experimental & 1.98 & 2.27 & 2.82 & 2.84 & 3.87 & 5.54 \\
& Model & 1.52 & 1.87 & 2.37 & 2.83 & 3.72 & 4.58 \\
\hline Dec & Model & 1.52 & 1.57 & 1.98 & 2.82 & 2.89 & 4.54 \\
& & & & & & & \\
\end{tabular}




$\begin{array}{lllllll}\text { Experimental } & 1.18 & 1.69 & 2.12 & 2.22 & 2.87 & 3.64\end{array}$

The linear regression analysis was carried out as explained in section 3 and the results were potted for big dome for $\mathrm{h}=0.75 \mathrm{~m}$ as follows in Fig. 2 .

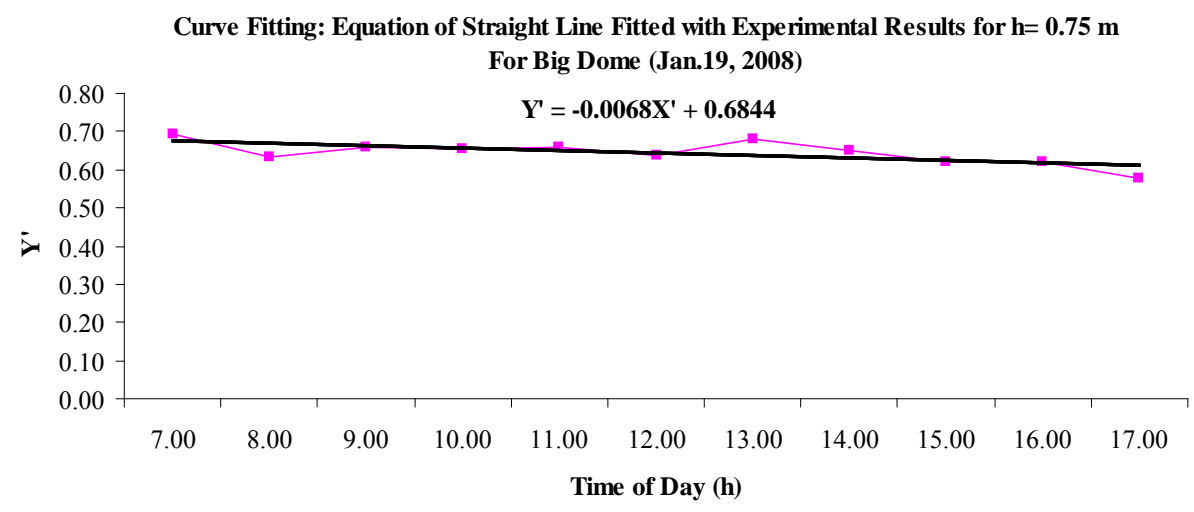

Fig.2. Linear regression of experimental results for big dome at $h=0.75 \mathrm{~m}$

The validation of daylight factor (DF) using experimental data of daylight factor for big and small domes at three different heights above floor surface were carried out for January and June based on the prediction of developed skylight model Eq.(2) and plotted as shown in Fig.3 (for January). The annual average energy saving potential for three heights for big and small domes were determined for selected locations in India and plotted as shown in Fig.4.

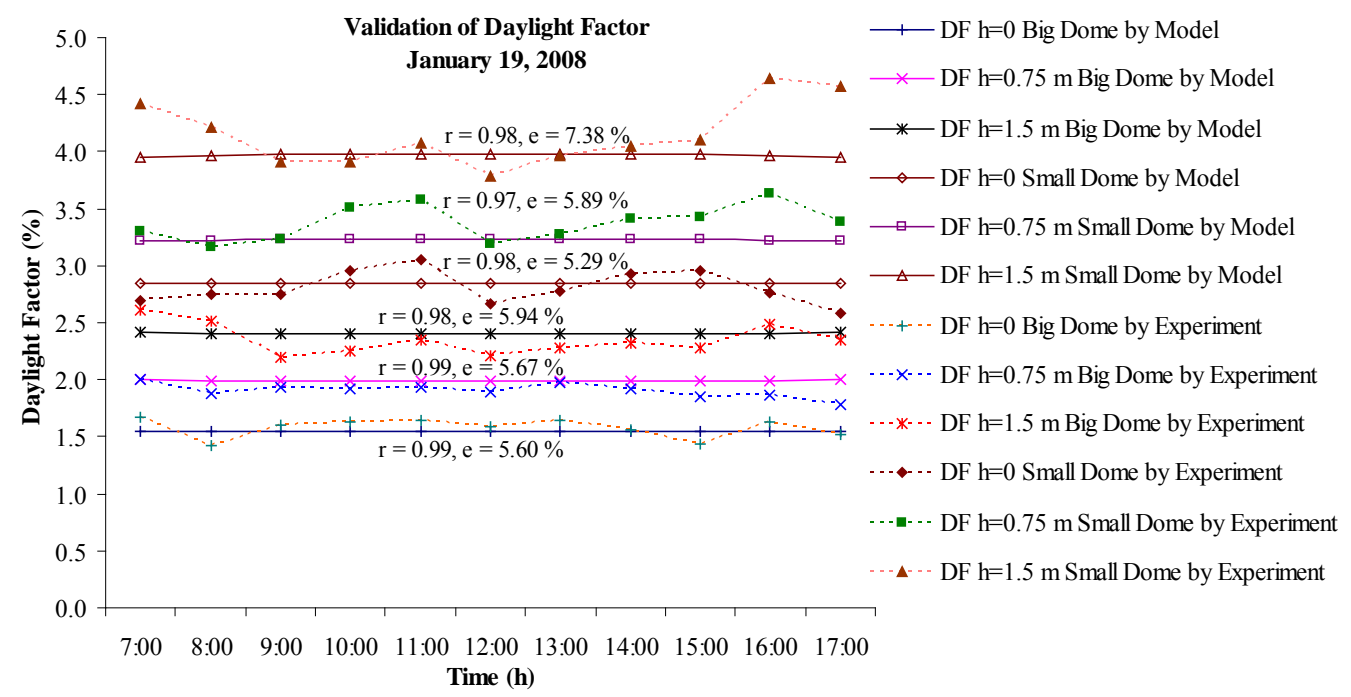

Fig.3. Validation of daylight factor model for big and small dome in January

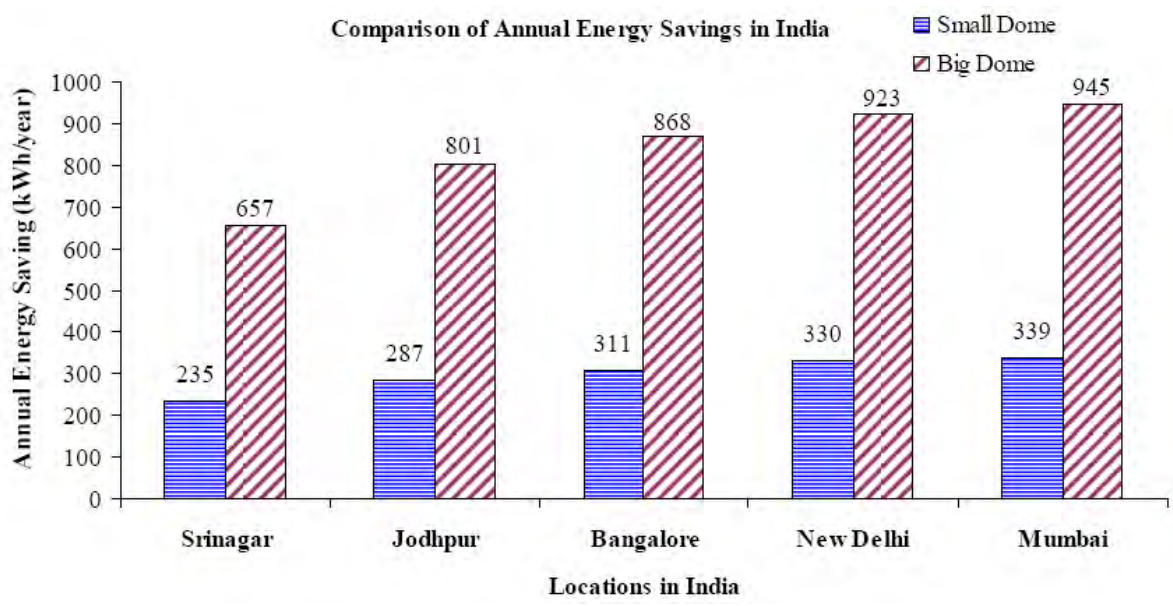


Fig.4. Annual energy saving potential of skylight for big dome room in India

\section{Conclusions}

The following key conclusions can be drawn from the study as follows:

1. It is found that the root mean square percentage error is small and varies in the range of 5$8 \%$ for the developed model Eq.(2). Hence, the proposed daylight factor model represented by Eq.(2) can be used to estimate the daylight factor (\%) and corresponding inside illuminance at different vertical heights in skylight integrated dome shape roof mud-house which can be seen from Figs.5.

2. The illuminance level inside the mud-house was found sufficient for office work inside the room from 9 am to $5 \mathrm{pm}$. The small dome room has maximum illuminance value (for $\mathrm{h}=$ $0-1.5 \mathrm{~m}$ ) in the range of 450-650 lux (in winter) and 800-1800 lux (in summer) while big dome room with maximum illuminance value (for $\mathrm{h}=0-1.5 \mathrm{~m}$ ) 250-400 (in winter) and 400-900 lux (in summer) in New Delhi (India).

3. The illuminance level was found $1001 \mathrm{ux}$ (minimum) inside both small dome and big dome rooms from 9 am to $4 \mathrm{pm}$ in all months of the year in New Delhi composite climatic conditions.

4. The experimental daylight factor over the year for big dome room (for $\mathrm{h}=0-1.5 \mathrm{~m}$ ) are found in the range of $1.5-2.5 \%$ (January) and $1.5-3.5 \%$ (June) while for small dome rooms (for $\mathrm{h}=0-1.5 \mathrm{~m}$ ) it varies in the range of 2.5-4.5\% (January) and 3-7.5 (June) based on skylight performance in both winter and summer. The annual average value of percentage daylight factor (for $\mathrm{h}=0-1.5 \mathrm{~m}$ ) is determined as $2.3 \%$ and $4.4 \%$ for big and small dome skylight rooms respectively. Hence, the skylight rooms are suitable for office building, e.g. state government offices in rural and urban areas of India, temple, church, mosque, etc.

5. The vertical height $(\mathrm{h})$ of work plane above floor surface for the skylight room gets significantly different amount of illuminance. This effect shows that distance of work plane from skylight is directly proportional to amount of illuminance received on that work plane surface. This can be observed from different values of daylight factor (\%) at different vertical height $(\mathrm{h})$ above floor for working surfaces inside big and small dome rooms.

\section{References}

[1] Webb AR. Considerations for lighting in the built environment: non-visual effects of light. Energy Build 2006; 38(7):721-7.

[2] Chel A, Tiwari GN, Chandra A. A model for estimation of daylight factor for skylight: an experimental validation using pyramid shape skylight over vault roof mud-house in New Delhi (India). Appl Energy 2009; 86(11):2507-19.

[3] Aries MBC, Newsham GR. Effect of daylight saving time on lighting energy use: a literature review. Energy Policy 2008; 36(6):1858-66.

[4] Building Research Establishment (BRE). Energy consumption guide 19, Energy use in offices, energy efficiency best practice programme, BRECSU Enquiries Bureau, Garston, Watford; 1997.

[5] Guide F. Energy efficiency in buildings, Chartered Institute of Building Services Engineers (CIBSE); 1999.

[6] Peacock AD, Newborough M, Banfill PFG. Technology assessment for the existing builtasset base (TARBASE), WREC, Aberdeen; 22-27 May 2005.

[7] Greenup P, Bell JM, Moore I. The importance of interior daylight distribution in buildings on overall energy performance. Renew Energy 2001; 22(1-3):45-52. 
[8] Reinhart CF. Lightswitch-2002: a model for manual and automated control of electric lighting a blinds. Solar Energy 2004; 77(1):15-28.

[9] Li DHW, Lam JC. An analysis of lighting energy-savings and switching frequency for a daylit corridor under various indoor design illuminance levels. Appl Energy 2003; 76(4):363-78.

[10] Franzetti C, Fraisse G, Achard G. Influence of the coupling between daylight and artificial lighting on thermal loads in the office buildings. Energy Build 2004;36(2):117-26.

[11] Lee ES, Bartolomeo DLD, Selkowitz SE. Daylighting-control performance of a thin-film ceramic electrochromic window: field study results. Energy Build 2006;38(1):30-44.

[12] Tong TDW, King Sing L, Cheung TM, Leung CS. Potential energy saving for a side-lit room using daylight-linked fluorescent lamp installations. Light Res Technol 2002;34(2):121-33.

[13] Smith GB. Materials and systems for efficient lighting and delivery of daylight. Solar Energy Mater Solar Cells 2004; 84(1-4):395-409.

[14] Reinhart C, Fitz A. Findings from a survey on the current use of daylight simulations in building design. Energy Build 2006; 38(7):824-35.

[15] ASHRAE, Fundamentals handbook; 2001 [chapter 29].

[16] Guide A. Environmental design, Chartered Institute of Building Services Engineers (CIBSE); 2006.

[17] Hunt DRG. Availability of daylight, Department of Environment, London, Building Research Establishment (BRE) Report, Garston, Watford; 1979.

[18] Hunt DRG. The use of artificial lighting in relation to daylight levels and occupancy. Build Environ 1979; 14(1):21-33.

[19] Stokes M, Rylatt M, Lomas K. A simple model of domestic-lighting demand. Energy Build 2004; 36(2):103-16.

[20] Mahlia T, Said M, Masjuki H, Tamjis M. Cost-benefit analysis and emission reduction of lighting retrofits in residential sector. Energy Build 2005;37(6):573-8.

[21] Laouadi A, Reinhart CF, Bourgeois D. Efficient calculation of daylight coefficients for rooms with dissimilar complex fenestration systems. J Build Perform Simulat 2008;1(1):3-15.

[22] Tregenza PR, Waters IM. Daylight coefficients. Light Res Technol 1983; 15(2):65-71.

[23] Rosa AD, Ferraro V, Kaliakatsos D, Marinelli V. Calculating indoor natural illuminance in overcast sky conditions. Appl Energy 2010; 87(3):806-13.

[24] Joshi M, Sawhney RL, Buddhi D. Estimation of luminous efficacy of daylight and exterior illuminance for composite climate of Indore city in Mid Western India. Renew Energy 2007; 32(8):1363-78.

[25] Chartered Institute of Building Services Engineers (CIBSE), Daylighting and window design, Lighting Guide 10; 1999.

[26] Chel A, Tiwari GN. Performance evaluation and life cycle cost analysis of earth to air heat exchanger integrated with adobe building for New Delhi composite climate. Energy Build 2009;41(1):56-66.

[27] Chel A, Tiwari GN. Thermal performance and embodied energy analysis of a passive house case study of vault roof mud-house in India. Appl Energy 2009; 86(10):1956-69.

[28] Chel A, Tiwari GN. Stand-alone photovoltaic (PV) integrated with earth to air heat exchanger (EAHE) for space heating/cooling of adobe house in New Delhi (India). Energy Convers Manage 2010; 51(3):393-409.

[29] Laouadi A, Atif MR. Daylight availability in top-lit atria: prediction of skylight transmittance and daylight factor. Light Res Technol 2000; 32(4):175-86.

[30] Chel A., Tiwari G.N. and Singh H.N. A modified model for estimation of daylight factor for skylight integrated with dome roof structure of mud-house in New Delhi (India), Appl Energy 2010; 87(10): 3037-50. 
[31] Jenkins D, Newborough M. An approach for estimating the carbon emissions associated with office lighting with a daylight contribution. Appl Energy 2007; 84(6):608-22. 